dischen Sprachen Verwandte, z. B. norw. kvekke "vor Schreck zusammenfahren', schwed. dial. väcka te 'zucken, zusammenfahren, schütteln'. Wie diese Wörter : zeigen, ist die Bedeutung 'abnehmen, verschwinden' in færø̈. huøkka sékundär entwickelt und kann also nicht als Argument für direkte Zusammenstellung mit čeznąti verwendet werden.

Die genannten nordischen Worte führe ich auf germ. *huinkan zurück. Es ist eine bekannte Tatsache, daß nk westnordisch zu kk wird, aber auch im Schwedischen kommt dieser Wandel vereinzelt vor (z. B. in Västergötland).

Ferner ist meines Erachtens eng. dial. whink 'Funke'. verwandt. Diese Bedeutung mag sich aus 'schnell fahren, zucken, und ähnl.' entwickelt haben. Vgl. eng. spark 'Funke' aus ags. spearca dass. zu ai. sphürjati 'bricht hervor', lat. spargo 'hinstreuen, sprengen, spritzen'.

Was mich vor allem bewogen hat, gegen Zupitzas Erklärung des $k k$ ins Feld zu ziehen, ist der Umstand, dảß wir offenbar eine Parallelform mit vorangesetztem $s$ - in schwed. dial. skväcka 'schütteln, rütteln' (besonders von einem Wagen) haben, welches ich auf germ. *skuinkan zurückführe. Hiermit verwandt ist augenscheinlich eng. dial. squink 'to squint, wink; to move the eyes from side to side'. Aller Wahrscheinlichkeit nach ist es aus dem Nordischen entlehnt.

Germ. *huinkan, skuinkan führe ich auf idg. * $q^{u} e n \hat{g}-,{ }^{*} s q^{u} e n \hat{g}-$ zurïck, aus idg. ${ }^{*}(s) q^{u} e \hat{g}$ - nasaliert, welche Wurzel in lat. conquinisco, conquexxi 'sich niederbücken', coxim 'zusammenkauernd, hockend' vorliegt. Ferner gehören hierher aisl. hvika hvak 'sich ducken, zusammenfahren' und abg. čeznạti.

Lund.

Herbert Petersson.

\title{
The Etymology of the Girnār word Petenika-.
}

On the fifth edict of the Girnār redaction of Asoka's Fourteen-Edicts, Petenika-, the name of a southern people occurs. Buehler, ZDMG. 37, p. 262, rejected the previous connection with Pratișțāna-, Païthāna- on linguistic grounds, ${ }^{1}$ ) and

1) The phonetic equivalent of Sanskrit Pratişthāna- would be *Pratistana- in our dialect. I have made the orthography uniform in this paper, so that $\dot{m}$. $\tilde{m}$, and $m$, for example, are given as $\dot{m}$. 
proposed a new etymology, namely that Petenika- was a compound, standing for Pretāyanika- or Präitāyanika-. Now although the rejection of the current etymology was correct, yet there are some phonetic objections to his own etymology: For medial aya remains otherwise unchanged in the dialect of this version ${ }^{1}$ ) of the Fourteen-Edicts; and I know of no parallel contraction of ăya to $e$ in Pāli: moreover Pischel, in his Grammar, does not record such a change as taking place in any of the Präkrit languages. Another point is that the lingual $n$ of Petenika- is left unaccounted for: the intervening $t$ of course would prevent the $r$ from converting a dental $n$ to a lingual $\dot{n}$. It is true that it is assumed that dental $n$ becomes lingual $n$ spontaneously a few times in our dialect (cf. Franke, Pāli und: Sanskrit p. 111); and if this were so, the $n$ would be no bar. But this assumption is, it would seem, erroneous. Indic $r s$. converts a following intervocalic dental $n$ to a lingual $n$. This : vimānadasanā, hastidasanā, dasane as contrasted with Sanskrit daršana-. So far as I know, this phonetic law has not been stated before. The sole apparent exception is dasanam in the eighth edict; the dental $n$ is a 'Māgadhism²)' for native $n:$ cf. Kälsi vimănadasanā, Dhauli vimānadasanam, Kālsī, Dhauli, and Jaugaḍa dasane. (Buehler's kâranam in the fourteenth: edict is a misprint for kāranam as is shown by the facsimile, and so not a parallel.) An intervening palatal consonant naturally would prevent the lingualization of a following intervocalic $n$; we

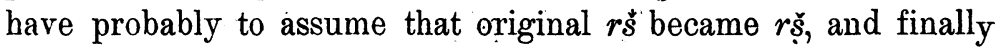
ss (which of course on our inscription is written s). This secondary $r \grave{s}$ could have the same lingualizing effect as original $r \grave{s}$. Since, however, original arș as well as aršs̆ become ās (e. g. vāsa-, kāsamti *karşșianti; cf. Skt. karišyanti; kăsamiti on the seventh,

1) So too in the dialects of the other versions, save that in the Jaugada one we chance to have lacunas where we otherwise would find test-cases.

2) For the benefit of those who are not specialists, I mention that it is a recognized fact that the Girnār, Shāhbāzgarhi, and Mansehra redactions of the Fourteen-Edicts are translations of an original composed in a dialect essentially the same as that of the Dhauli, Jaugada, and Kālsī (edicts i-ix) redactions of the Fourten-Edicts, etc., and that this dialect has left traces in the transiations. These traces are called 'Magadhisms' as the dialect of the original was Mãgadhan (cf. the change of $r$ to $l$ in the dialect of Dh., etc. as in Māgadhī Prākrit). 
and dasavăsābhisito on the eighth edict are merely blunders as are etārisăni of the eighth, and dănam, etärisam and ñătikena of the nineth), original $r \dot{s}$ could not have reached the stage $r \grave{s}$ until original arş and arşi had become $\bar{a} s$, for original arš becomes ass (written as) in our dialect. Of course there is no reason why the same combination of sounds in different periods might not develope differently even in the same dialect. It may be added that apart from the combinations cited, Indic $\dot{s}$ and $\check{s}$ fall together absolutely, becoming $s$... The lingual $n$ of Girnār prāpunati, Shāhbāzgarhi prapunati, and Pāli pāpuṇāti (and papunoti) is more original than the dental $n$ of Sanskrit prāpnoti: this last is analogical; cf. Wackernagel, AiGr. i. $\$ 168$. ... There remains only the lingual $n$ of kalanna- to be accounted for. But the same $n$ appears in Shāhbāzgarhi and Mansehra kalana- (the $l$ of the G., Shb., and Man. word is merely graphic for $l l ; a$ and $\bar{a}$ are not distinguished in the alphabet in which the Shb. and Man. versions are written), Pāli kallāna-, kalyāna- (dialectic doublets), and Sanskrit kalyāna-. So that this $\boldsymbol{n}$ is not peculiar to the dialect of the Girnār redaction of Asoka's Fourteen-Edicts. Hence any explanation of it must satisfy the phonetic requirements of all the languages cited. On the word see Wackernagel, l. c. $\S \S 172 \mathrm{c}$ fine print, 173 fine print, $174 \mathrm{~b}$ fine print, and the literature cited there.

For the reasons stated above, I must decline to accept Buehler's etymology of the word in question, and offer another. A compound of Indic *pitr- (Skt. pitr-) and *aiana- (Skt. ayana-) would appear as *pitraiana- with lingual $n$. Now a vrddhi-derivative adjective in -ika- from *pitraiana- would be *päitraianika-. From this last Petenika- comes without difficulty ${ }^{1}$ ).- It may be pointed out that the meaning of *paitraianika- and Buehler's Pretāyanika- (or Präi-) is identical.

We have next to consider the correspondents of the other versions (where extant) to Girnār Petenika-. Dhauli Pi(t)enikahas a dental $n$ : but it will be remembered that the lingual nasal is lacking in the dialects of the Dhauli, Jaugada, and Kālsi redactions of the Fourteen-Edicts as well as in the dialects of the various recensions of the Pillar-Edicts; corresponding to

1) The $t$ of Petenika- is, of course, a 'Măgadhism' for native $t v$ as is the $t$ of -puto in Ketalaputo. The contraction of $a j a$ (aya) to $e$ under unknown conditions is Pan-Middle-Indic. 
Sanskrit $n$ the dialects named have $n$ and this only. Hence the dental $n$ of Pi(t)enika- is quite in place. The difference in the vocalism of the first syllable is due to the fact that Petenikais a vrddhi-derivative but $P i(t) e n i k a-$ a simple derivative. Shāhbāzgarhi and Mansehra Pitinika- is a 'Māgadhism' as is shown by the plain $t$ for native $t r$ and the dental $n$ for native $n$. Similarly Mansehra Amdha- is a 'Māgadhism' for Amdhra- (so the Shāhbāzgarhi redaction). A parallel case where we have 'Māgadhan' dental $n$ for native lingual $n$ is Shāhbāzgarhi Tambapamni (Skt. Tämraparñ̄) in the second edict'1): cf. Girnār Tambapamnī but Kälsī Tä̈bapamni. The Mansehra text in the corresponding passage reads. bapani, i. e. Tabapani. This stands for Tambapamini. The native $n$ will be observed. It should be noticed that Tambapamniya at Shb. XIII. 9, Man. XIII. 10 also has 'Māgadhan' $n$ (Kālsĩ Tambapamniyā, XIII. 8). The $i$ of the second syllable of Pitinika- is for $e$ as in Shb., Man. ayi (a hyper-Māgadhism for ayo), Shb. duvi, rajani etc. ... We next come to Kâlsi Pitinikya- ${ }^{2}$ ). The $k y$ corresponds to the $k$ of the other dialects as the $k y$ of akālikye, etc. and the $i$ for $e$ in the second syllable has a parallel in asamati (Sanskrit asamāptah). Ridgefield, Connecticut.

Truman Michelson.

\section{Zn IF. 22, 193 ff.}

Herr Dr. R. Trautmann, Göttingen, macht mich freundlichst darauf aufmerksam, daß schon Bezzenberger BB. 23, 318 apreuß. walis mit got. walus verbunden hat; ebenso daß apreuß. picle „czimar" nicht (Ochsen)ziemer, sondern den Vogel Ziemer meint, womit die von mir vorgeschlagene Etymologie hinfällig wird. Kiel.

Hein rich Schröder.

1) Johansson is in error when he assumes that the $\dot{m} n$ of this word is merely graphical for $\dot{m} n$, i. e. $n n: n$ elsewhere in both the Shāhbāzgarhi and Mansehra redactions of the Fourteen-Edicts represents dental $n$ and this only; hence it should be considered as representing this in the present instance: in any case the fact that the $\dot{m} b$ is a 'Mãgadhism" - and Johansson admits this - would make us suspect that the $\dot{m} n$ was also one.

2) The Kālsi recension has no correspondent to Petenika- in the fifth edict, but has the equivalent of it in the thirteenth edict. 